\title{
Faktor-Faktor yang Mempengaruhi Kunjungan Nifas Lengkap di Indonesia: Analisis Lanjut Data Riskesdas 2018
}

\author{
Marlina Hendryka Situmorang, Pujiyanto \\ Fakultas Kesehatan Masyarakat, Universitas Indonesia
}

\begin{abstract}
Abstrak
Latar Belakang: Perawatan nifas dibutuhkan pada periode setelah persalinan untuk mendeteksi dini masalah atau mengobati penyakit pascapersalinan. Lebih dari 65\% kematian ibu terjadi selama 42 hari pertama pascapersalinan. Penelitian ini bertujuan untuk menganalisis faktor-faktor yang mempengaruhi kunjungan nifas lengkap di Indonesia.

Metode: Penelitian menggunakan data Riset Kesehatan Dasar (Riskesdas) 2018. Unit analisis penelitian ini adalah ibu yang melahirkan anak terakhir dalam kurun 2013 sampai wawancara Riskesdas 2018.

Hasil: Berdasarkan hasil regresi logistik, faktor predisposisi yang memiliki peluang untuk mempengaruhi kunjungan nifas lengkap adalah umur ibu 20-35 tahun (OR 0,885), pendidikan tinggi (OR 1,167), paritas $\leq 2($ OR 1,090), persalinan secara sesar/vacuum/forceps, dll (OR 1,491), persalinan di fasilitas kesehatan $(O R$ 1,489), pemeriksaan kehamilan lengkap $(O R$ 1,613), dan regional Sumatera (OR 0,510). Faktor pemungkin yang memiliki peluang untuk mempengaruhi kunjungan nifas lengkap adalah status tidak bekerja $($ OR 0,954) dan memiliki jaminan kesehatan (OR 1,141). Faktor kebutuhan yang memiliki peluang untuk mempengaruhi kunjungan nifas lengkap adalah memiliki riwayat komplikasi kehamilan (OR 0,948).

Kesimpulan: Faktor-faktor yang mempengaruhi kunjungan nifas lengkap adalah umur ibu, pendidikan, paritas, metode persalinan, tempat persalinan, pemeriksaan kehamilan, regional tempat tinggal, status pekerjaan, kepemilikan jaminan kesehatan, dan riwayat komplikasi kehamilan.

Kata Kunci: determinan, kunjungan nifas, postnatal care, postpartum, PNC
\end{abstract}

\section{The Determinants of Fully Postpartum Visit in Indonesia: Further Analysis of Riskesdas 2018}

\begin{abstract}
Abstrac
Background: Post-natal care is needed during postpartum for early detection or to cure disease or any problem of postpartum. More than $60 \%$ of maternal mortality happens during 42 days of postpartum. This research is intended to analyse the determinant factors of fully postpartum visit in Indonesia.

Method: This research uses the data from Riskesdas 2018. The unit of analytic research is mothers having last birth happened from 2013 until Riskesdas interview on 2018.

Result: Based on the result of logistic regression, predisposition factors that have chance to affect the fully postpartum visit are mothers on age 20-35 years old (OR 0,885), advance education (OR 1,167), parity $\leq 2$ (OR 1,090), laboring through caesar, vacuum, forceps et all (OR 1,491), labor using medical facility (OR 1,489), fully pregnancy checkup $(O R$ 1,613) and region Sumatera $(O R$ 0,510). Enabling factors that have chance to affect the fully postpartum visit are unemployment $(O R 0,954)$ and owning health insurance $(O R 1,141)$. Need factor that has chance to affect fully postpartum visit is having history of pregnancy complications (OR 0,948).

Conclusion: The factors affecting fully postpartum visit are age, education, parity, labor method, place of labor, pregnancy checkup and region of province, job status, health insurance ownership and history of pregnancy complication.

Keywords: determinant, postpartum visit, postnatal care, postpartum, PNC
\end{abstract}

Koredpondensi: Marlina Hendryka S.

Email: marlinakenzie@gmail.com 


\section{PENDAHULUAN}

Angka kematian ibu (AKI) di Indonesia masih tinggi jika dibandingkan dengan semua negara-negara ASEAN lainnya dan target yang ditetapkan Kementrian Kesehatan (Kemenkes), dimana pada tahun 2016 angka kematian ibu 305/100.000 kelahiran hidup diatas rata-rata AKI di ASEAN yaitu 234,6/100.000 kelahiran hidup. ${ }^{1}$ Pada tahun 2017, AKI di Indonesia sebesar 177 kematian per 100 ribu kelahiran hidup $^{2}$. Hal ini masih jauh dari target pencapaian Tujuan Pembangunan Berkelanjutan (SDGs) sebesar 70 kematian per 100.000 kelahiran hidup dan target Kemenkes RI sebesar 131 per 100.000 kelahiran hidup pada tahun $20300^{3,4}$

Lebih dari $65 \%$ kematian ibu terjadi selama 42 hari setelah melahirkan. ${ }^{5}$ Komplikasi utama yang menyebabkan hampir $75 \%$ dari semua kematian ibu adalah perdarahan hebat (kebanyakan perdarahan setelah melahirkan), infeksi (biasanya setelah melahirkan), tekanan darah tinggi selama kehamilan (pre-eklamsia dan eklamsia), komplikasi dari persalinan, dan aborsi tidak aman ${ }^{6}$. Keluhan paling umum dari kunjungan masa nifas adalah demam (30,3\%), masalah pada episiotomi atau bekas luka operasi $(26,6 \%)$ dan sakit perut $(25,7 \%) .{ }^{7}$ Hasil studi di tiga kabupaten dan kota di Banten menemukan bahwa 34\% kematian ibu terjadi pada saat persalinan/dalam 24 jam pascapersalinan sementara $25 \%$ terjadi di pascapersalinan 8-42 hari, dimana kematian ini disebabkan oleh perdarahan obstetric 38,3\%, preeklampsia/eklampsia $19,1 \%$, dan anemia pada kehamilan $13,6 \%{ }^{8}$

Hasil penelitian tentang Disparity of Maternal Mortality in Indonesia, didapatkan hasil bahwa $61,4 \%$ dari total kabupaten/kota di Indonesia yang cakupan kunjungan nifas (KF) rendah memiliki angka kematian maternal tinggi. Sedangkan $61,8 \%$ dari total kabupaten/kota yang cakupan kunjungan nifas (KF) tinggi memiliki angka kematian maternal rendah. ${ }^{9}$

Perawatan nifas bertujuan untuk menjaga kesehatan ibu dan bayinya, mendeteksi dini masalah, penyakit dan penyulit pascapersalinan, memberikan Komunikasi, Informasi, Edukasi (KIE), melibatkan keluarga dalam menjaga kesehatan ibu nifas dan bayi baru lahir serta memberikan pelayanan KB sesegera mungkin setelah persalinan. Menurut Kemenkes, pelayanan kesehatan ibu yang diperoleh selama 42 hari selama melahirkan, paling sedikit 3 kali meliputi kunjungan nifas 1 (6 jam hingga 3 hari setelah melahirkan), kunjungan nifas 2 (4 hingga 28 hari setelah melahirkan) dan kunjungan nifas 3 (29 sampai 42 hari setelah melahirkan). ${ }^{10}$

Hasil Riskesdas tahun 2010 s/d 2018 menunjukkan bahwa kunjungan nifas lengkap di Indonesia mengalami sedikit kenaikan dari $32,1 \%$ (2013) menjadi 45,2\% dari total 78.812 ibu yang melahirkan (2018), sedangkan di tahun 2010 kunjungan nifas pertama kali setelah melahirkan (0-1 hari) berkisar 29,9\%$32,6 \%{ }^{11}$ Namun, jumlah ini masih rendah mengingat kunjungan nifas merupakan upaya penting dalam menurunkan angka kematian ibu dan anak. Oleh karena itu, penulis melakukan penelitian tentang faktor-faktor yang mempengaruhi kunjungan nifas lengkap di Indonesia.

\section{METODE PENELITIAN}

Penelitian ini menggunakan data sekunder, yaitu data Riskesdas 2018. Unit analisis yang digunakan adalah ibu yang melahirkan dengan kelahiran anak terakhir sejak 2013 sampai wawancara Riskesdas 2018. Sampel di dalam analisis ini adalah 76.484 wanita berusia 15-54 tahun dengan kriteria inklusi pernah kawin dan melahirkan anak terakhir hidup. Analisis bivariat pada penelitian ini menggunakan chi square untuk menganalisis faktor yang mempengaruhi kunjungan nifas dan analisis multivariat menggunakan regresi logistik untuk melihat pengaruh variabel bebas secara bersama-sama terhadap kunjungan nifas lengkap di Indonesia pada tahun 2013-2018.

Penelitian ini menggunakan teori Anderson dan Newman tentang Societal and Individual Determinants of Medical Care Utilization. Dalam analisis ini, variabel terikat adalah kunjungan nifas lengkap dibagi menjadi dua kategori yaitu ya dan tidak. Kategori ya apabila ibu telah memperoleh minimal 3 kali pelayanan selama nifas dari tenaga kesehatan sesuai standar yaitu kunjungan nifas 1 (6 jam hingga 3 hari setelah melahirkan), kunjungan nifas 2 (4 hingga 28 hari setelah melahirkan) dan kunjungan nifas 3 (29 sampai 42 hari setelah melahirkan). Kategori tidak jika tidak memenuhi standar tersebut.

Variabel tidak terikat adalah faktor predisposisi (wilayah tempat tinggal, umur, pendidikan, paritas, metode persalinan, tempat persalinan, pemeriksaan kehamilan dan 
regional propinsi), faktor pemungkin (status pekerjaan, kepemilikan jaminan kesehatan), faktor kebutuhan (riwayat komplikasi kehamilan, riwayat komplikasi persalinan dan komplikasi nifas).Wilayah tempat tinggal adalah pembagian unit yang terkecil dari domisili responden, yang dikategorikan menjadi dua yaitu perkotaan dan pedesaan. Umur ibu adalah lamanya hidup wanita sejak dia lahir sampai dengan melahirkan anak, yang dikategorikan menjadi dua yaitu 20 sampai 35 tahun dan kurang dari 20 tahun diatas 35 tahun.

Pendidikan ibu merujuk pada pendidikan formal terakhir yang diperoleh ibu saat melahirkan, yang dikategorikan menjadi tinggi (tamat D1/D2/D3 dan PT), sedang (tamat SLTA/MA) dan rendah (tidak/belum pernah sekolah, tidak tamat SD/MI, tamat SD/MI, tamat SLTP/MTS). Paritas adalah jumlah anak yang pernah dilahirkan oleh ibu baik lahir hidup maupun lahir hidup meninggal, yang dikategorikan menjadi dua yaitu kurang sama dengan dua dan lebih dari dua.

Metode persalinan adalah cara/metode keluarnya janin pada proses kehamilan, yang dikategorikan menjadi dua yaitu operasi sesar, vacuum, forceps, lainnya dan normal. Tempat persalinan adalah tempat bayi dilahirkan atau tempat dimana penolong persalinan memberikan bantuan persalinan, dikategorikan menjadi dua yaitu fasilitas kesehatan dan non fasilitas kesehatan.

Pemeriksaan kehamilan adalah pemeriksaan kandungan dan kesehatan ibu oleh petugas kesehatan yaitu dokter spesialis kandungan, dokter umum, bidan dan perawat. Pemeriksaan kehamilan dibagi menjadi dua kategori yaitu lengkap (jika ibu memeriksakan kehamilannya minimal satu kali pada trimester pertama, minimal satu kali pada trimester kedua, dan minimal dua kali pada trimester ketiga) dan tidak lengkap (jika tidak memenuhi kriteria di atas). Regional propinsi adalah pengelompokan propinsi berdasarkan wilayah daerah yang saling berdekatan, dikategorikan menjadi Sumatera, Jawa-Bali, Kalimantan, Sulawesi dan Nusa Tenggara-Maluku-Papua.

Status pekerjaan adalah pekerjaan utama responden yang menggunakan waktu terbanyak atau pekerjaan yang memberikan penghasilan terbesar, yang dikategorikan menjadi dua yaitu bekerja dan tidak bekerja. Kepemilikan jaminan kesehatan adalah asuransi/jaminan kesehatan yang dimiliki ibu pada saat melahirkan, dibagi menjadi dua kategori yaitu ada dan tidak ada.

Riwayat komplikasi kehamilan adalah ada tidaknya salah satu atau lebih keadaan/ tanda tanda bahaya yang dialami ibu saat kehamilan, dikategorikan menjadi dua yaitu ada dan tidak ada. Riwayat komplikasi persalinan adalah ada tidaknya salah satu atau lebih keadaan/ tanda tanda bahaya yang dialami ibu saat melahirkan, dikategorikan menjadi dua yaitu ada dan tidak ada. Komplikasi nifas adalah komplikasi yang terjadi pada saat nifas, yang dikategorikan menjadi ada dan tidak ada.

\section{HASIL PENELITIAN}

Hasil penelitian ini menunjukkan bahwa dari 76.484 ibu yang melahirkan dengan kelahiran anak terakhir yang terjadi sejak 2013 sampai 2018, terdapat sebanyak 25.060 orang $(32,8 \%)$ yang melakukan kunjungan nifas lengkap. Sedangkan yang melakukan kunjungan nifas (KF) 1 adalah 58.779 (76,9\%), KF 2 sebanyak $46.576(60,9 \%)$, dan KF 3 sebanyak $30.519(39,9 \%)$.

Tabel 1. Analisis Bivariat Hubungan Faktor Predisposisi, Faktor Pemungkin dan Faktor Kebutuhan dengan Kunjungan Nifas Lengkap di Indonesia

\begin{tabular}{|c|c|c|c|c|c|c|c|}
\hline \multirow{3}{*}{ Variabel } & \multicolumn{4}{|c|}{ Status Kunjungan Nifas Lengkap } & \multirow{2}{*}{\multicolumn{2}{|c|}{ Jumlah }} & \multirow{3}{*}{$\begin{array}{c}\mathbf{P} \\
\text { Value }\end{array}$} \\
\hline & \multicolumn{2}{|c|}{$\mathbf{Y a}$} & \multicolumn{2}{|c|}{ Tidak } & & & \\
\hline & $\mathbf{N}$ & $\%$ & $\mathbf{N}$ & $\%$ & $\mathbf{N}$ & $\%$ & \\
\hline \multicolumn{8}{|c|}{ a. $\quad$ Faktor Predisposisi } \\
\hline \multicolumn{8}{|c|}{ Wilayah } \\
\hline Perkotaan & 11.679 & 37,3 & 19.648 & 62,7 & 31.327 & 100 & 0,000 \\
\hline Pedesaan & 13.381 & 29,6 & 31.776 & 70,4 & 45.157 & 100 & \\
\hline \multicolumn{8}{|l|}{ Umur Ibu } \\
\hline 20-35 tahun & 17.938 & 32,4 & 37.503 & 67,6 & 55.441 & 100 & 0,000 \\
\hline 20 dan $>35$ tahun & 7.122 & 33,8 & 13.921 & 66,2 & 21.043 & 100 & \\
\hline \multicolumn{8}{|l|}{ Pendidikan Ibu } \\
\hline Tinggi & 4.294 & 40,9 & 6.217 & 59,1 & 10.511 & 100 & 0,000 \\
\hline
\end{tabular}




\begin{tabular}{|c|c|c|c|c|c|c|c|}
\hline Sedang & 8.479 & 34,6 & 16.034 & 65,4 & 24.513 & 100 & \\
\hline Rendah & 12.287 & 29,6 & 29.173 & 70,4 & 41.460 & 100 & \\
\hline \multicolumn{8}{|l|}{ Paritas } \\
\hline$\leq 2$ anak & 16.740 & 34,7 & 31.482 & 65,3 & 48.222 & 100 & \multirow[t]{2}{*}{0,000} \\
\hline$>2$ anak & 8.320 & 29,4 & 19.942 & 70,6 & 28.262 & 100 & \\
\hline \multicolumn{8}{|l|}{ Metode Persalinan } \\
\hline $\begin{array}{l}\text { Sesar, vacuum, forcep } \\
\text { dan alat lainnya }\end{array}$ & 5.875 & 45,5 & 7.036 & 54,5 & 12.911 & 100 & \multirow[t]{2}{*}{0,000} \\
\hline Normal & 19.185 & 30,2 & 44.388 & 69,8 & 63.572 & 100 & \\
\hline \multicolumn{8}{|l|}{ Tempat Persalinan } \\
\hline Fasilitas Kesehatan & 21.430 & 36,6 & 37.050 & 63,4 & 58.480 & 100 & \multirow{2}{*}{0,000} \\
\hline Non Fasilitas Kesehatan & 3.630 & 20,2 & 14.374 & 79,8 & 18.004 & 100 & \\
\hline \multicolumn{8}{|l|}{ Pemeriksaan Kehamilan } \\
\hline Lengkap & 19.329 & 37,6 & 32.023 & 62,4 & 51.352 & 100 & \multirow[t]{2}{*}{0,000} \\
\hline Tidak Lengkap & 5.731 & 22,8 & 19.401 & 77,2 & 25.132 & 100 & \\
\hline \multicolumn{8}{|l|}{ Regional propinsi } \\
\hline Sumatera & 6.307 & 26,7 & 17.332 & 73,3 & 23.639 & 100 & \multirow{5}{*}{0,000} \\
\hline Jawa - Bali & 10.401 & 44,5 & 12.991 & 55,5 & 23.392 & 100 & \\
\hline Kalimantan & 2.153 & 27,5 & 5.685 & 72,5 & 7.838 & 100 & \\
\hline Sulawesi & 2.739 & 26,6 & 7.561 & 73,4 & 10.300 & 100 & \\
\hline $\begin{array}{l}\text { Nusa Tenggara-Maluku- } \\
\text { Papua }\end{array}$ & 3.460 & 30,6 & 7.855 & 69,4 & 11.315 & 100 & \\
\hline \multicolumn{8}{|l|}{ b. Faktor Pemungkin } \\
\hline \multicolumn{8}{|l|}{ Status Pekerjaan } \\
\hline Tidak Bekerja & 13.144 & 32,0 & 27.891 & 68 & 41.035 & 100 & \multirow[t]{2}{*}{0,000} \\
\hline Bekerja & 11.916 & 33,6 & 23.533 & 66,4 & 35.449 & 100 & \\
\hline \multicolumn{8}{|l|}{ Kepemilikan Jaminan } \\
\hline \multicolumn{8}{|l|}{ Kesehatan } \\
\hline Ada & 12.586 & 37,4 & 21.042 & 62,6 & 33.628 & & \multirow[t]{2}{*}{0,000} \\
\hline Tidak Ada & 12.474 & 29,1 & 30.382 & 70,9 & 42.856 & & \\
\hline \multicolumn{8}{|l|}{ c. Faktor Kebutuhan } \\
\hline \multicolumn{8}{|l|}{ Riwayat Komplikasi } \\
\hline \multicolumn{8}{|l|}{ Kehamilan } \\
\hline Ada & 7.882 & 33,5 & 15.647 & 66,5 & 23.529 & 100 & \multirow[t]{2}{*}{0,004} \\
\hline Tidak Ada & 17.178 & 32,4 & 35.777 & 67,6 & 52.955 & 100 & \\
\hline \multicolumn{8}{|l|}{ Riwayat Komplikasi } \\
\hline \multicolumn{8}{|l|}{ Persalinan } \\
\hline Ada & 6.085 & 38,9 & 9.566 & 61,1 & 15.651 & 100 & \multirow[t]{2}{*}{0,000} \\
\hline Tidak Ada & 18.975 & 31,2 & 41.858 & 68,8 & 60.833 & 100 & \\
\hline \multicolumn{8}{|l|}{ Komplikasi Nifas } \\
\hline Ada & 2.671 & 34 & 5.174 & 66 & 7.845 & 100 & \multirow[t]{2}{*}{0,011} \\
\hline Tidak Ada & 22.389 & 32,6 & 46.250 & 67,4 & 68.639 & 100 & \\
\hline
\end{tabular}

Tabel 1 menunjukkan bahwa berdasarkan analisis bivariat, faktor predisposisi (wilayah tempat tinggal, usia ibu, pendidikan, paritas, metode persalinan, tempat persalinan, pemeriksaan kehamilan, regional propinsi), faktor pemungkin (status pekerjaan, kepemilikan jaminan kesehatan) dan faktor kebutuhan (riwayat komplikasi kehamilan, riwayat komplikasi persalinan, dan komplikasi nifas) memiliki hubungan yang signifikan dengan kunjungan nifas lengkap $(p<0,05)$, dimasukkan dalam model multivariat $(\mathrm{p}<0,25)$. 
Tabel 2. Analisis Multivariat Hubungan Faktor Predisposisi, Faktor Pemungkin dan Faktor Kebutuhan dengan Kunjungan Nifas Lengkap di Indonesia

\begin{tabular}{|c|c|c|c|}
\hline Variabel & Crude odds ratio & $95 \% \mathrm{Cl}$ & Pvalue \\
\hline \multicolumn{4}{|l|}{ a. Faktor predisposisi } \\
\hline \multicolumn{4}{|l|}{ Umur Ibu } \\
\hline 20-35 tahun & 0,885 & $(0,851-0,921)$ & 0,000 \\
\hline 20 dan $>35$ tahun & 1 & & \\
\hline \multicolumn{4}{|l|}{ Pendidikan ibu } \\
\hline Tinggi & 1,167 & $(1,110-1,227)$ & 0,000 \\
\hline Sedang & 1,285 & $(1,224-1,349)$ & 0,000 \\
\hline Rendah & 1 & & \\
\hline \multicolumn{4}{|l|}{ Paritas } \\
\hline$\leq 2$ anak & 1,090 & $(1,050-1,132)$ & 0,000 \\
\hline$>2$ anak & 1 & & \\
\hline \multicolumn{4}{|l|}{ Metode Persalinan } \\
\hline $\begin{array}{l}\text { Sesar, vacuum, forcep } \\
\text { dan alat lainnya }\end{array}$ & 1,491 & $(1,430-1,554)$ & 0,000 \\
\hline Normal & 1 & & \\
\hline \multicolumn{4}{|l|}{ Tempat Persalinan } \\
\hline Fasilitas Kesehatan & 1,489 & $(1,421-1,560)$ & 0,000 \\
\hline Non Fasilitas & 1 & & \\
\hline \multicolumn{4}{|l|}{ Kesehatan } \\
\hline \multicolumn{4}{|l|}{ Pemeriksaan Kehamilan } \\
\hline Lengkap & 1,613 & $(1,555-1,673)$ & 0,000 \\
\hline \multirow{2}{*}{\multicolumn{4}{|c|}{ Regional Propinsi }} \\
\hline & & & \\
\hline Sumatera & 0,510 & $(0,490-0,531)$ & \\
\hline Jawa - Bali & 0,883 & $(0,832-0,936)$ & 0,000 \\
\hline Kalimantan & 0,942 & $(0,892-0,994)$ & \\
\hline Sulawesi & 0,696 & $(0,662-0,733)$ & \\
\hline Nusa Tenggara - & 1 & & \\
\hline \multirow{2}{*}{\multicolumn{4}{|c|}{ b. Faktor Pemungkin }} \\
\hline & & & \\
\hline \multicolumn{4}{|l|}{ Status Pekerjaan } \\
\hline Tidak Bekerja & 0,954 & $(0,924-0,986)$ & 0,000 \\
\hline Bekerja & 1 & & \\
\hline Kepemilikan & & & \\
\hline \multicolumn{4}{|l|}{ Kesehatan } \\
\hline Ada & 1,141 & $(1,102-1,181)$ & 0,000 \\
\hline Tidak Ada & 1 & & \\
\hline \multicolumn{4}{|l|}{ c. Faktor Kebutuhan } \\
\hline Riwayat $\quad$ Kom & & & \\
\hline \multicolumn{4}{|l|}{ Kehamilan } \\
\hline Ada & 0,948 & $(0,916-0,980)$ & 0,000 \\
\hline Tidak ada & 1 & & \\
\hline
\end{tabular}

Tabel 2 menunjukkan bahwa berdasarkan hasil analisis regresi logistik, faktor-faktor yang mempengaruhi kunjungan nifas lengkap di Indonesia adalah faktor predisposisi (usia ibu, pendidikan, paritas, metode persalinan, tempat persalinan, pemeriksaan kehamilan, regional propinsi), faktor pemungkin (status pekerjaan, kepemilikan jaminan kesehatan) dan faktor kebutuhan (riwayat komplikasi kehamilan).

Peluang ibu yang berusia 20-35 tahun melakukan kunjungan nifas lengkap 0,885 kali dibandingkan ibu yang berusia $<20$ dan $>35$ tahun. Terkait pendidikan, ibu yang berpendidikan tinggi 1,167 kali lebih cenderung untuk melakukan kunjungan nifas lengkap dibandingkan ibu yang berpendidikan rendah.

Faktor predisposisi lainnya yang mempengaruhi kunjungan nifas lengkap adalah paritas, dimana peluang ibu dengan paritas $\leq 2$ anak 1,090 kali lebih cenderung untuk melakukan kunjungan nifas lengkap dibandingkan ibu dengan paritas $>2$ anak. Ibu 
yang melahirkan dengan metode sesar, vacuum, forcep dan alat lainnya 1,491 kali lebih cenderung untuk melakukan kunjungan nifas lengkap dibandingkan ibu yang yang melahirkan dengan normal. Ibu yang melahirkan di fasilitas kesehatan 1,489 kali lebih cenderung untuk melakukan kunjungan nifas lengkap dibandingkan ibu yang yang melahirkan di non fasilitas kesehatan.

Dalam hal pemeriksaan kehamilan, peluang ibu melakukan kunjungan nifas lengkap dengan pemeriksaan kehamilan lengkap 1,613 kali dibandingkan ibu dengan pemeriksaan kehamilan tidak lengkap. Ibu yang tinggal di regional Sumatera berpeluang melakukan kunjungan nifas lengkap 0,510 kali dibandingkan ibu yang tinggal di regional Nusa Tenggara - Maluku - Papua.

Faktor pemungkin yang juga mempengaruhi ibu melakukan kunjungan nifas lengkap antara lain status pekerjaan dan kepemilikan jaminan kesehatan. Peluang ibu yang tidak bekerja untuk melakukan kunjungan nifas lengkap 0,954 kali dibandingkan ibu yang bekerja. Dalam hal kepemilikan jaminan kesehatan, ibu yang memiliki jaminan kesehatan 1,141 kali lebih cenderung untuk melakukan kunjungan nifas lengkap dibandingkan ibu yang tidak memiliki jaminan kesehatan. Riwayat komplikasi kehamilan adalah faktor pemungkin yang juga mempengaruhi kunjungan nifas lengkap, dimana ibu yang memiliki riwayat komplikasi kehamilan berpeluang untuk melakukan kunjungan nifas lengkap 0,948 kali dibandingkan ibu yang tidak memiliki riwayat komplikasi kehamilan.

\section{PEMBAHASAN}

Hasil penelitian menunjukkan bahwa proporsi kunjungan nifas lengkap di Indonesia masih rendah $(32,8 \%)$ dibandingkan negaranegara lainnya seperti Benin (68\%), Zambia (63\%), Uganda (50\%). Hal ini merupakan perhatian penting karena pada masa nifas tidak sedikit ibu yang mengalami masalah kesehatan baik fisik maupun psikis dan tidak jarang berujung pada kematian ibu ${ }^{5}$. Berdasarkan hasil analisis multivariat, maka dapat diketahui seberapa besar pengaruh dan kecenderungan dari setiap variabel yang signifikan berpengaruh terhadap kunjungan nifas, dilihat dari besarnya nilai odds rasio (OR). Variabel yang memiliki OR>1 antara lain pendidikan, paritas, metode persalinan, tempat persalinan, pemeriksaan kehamilan dan kepemilikan jaminan kesehatan.

Penelitian menemukan kecenderungan kunjungan nifas lengkap akan semakin meningkat seiring meningkatnya pendidikan ibu. Semakin tinggi pendidikan ibu semakin banyak pengetahuan yang didapat sehingga sangat mempengaruhi ibu tersebut melakukan kunjungan nifas. Ibu berpendidikan tinggi cenderung lebih sadar akan masalah kesehatan, lebih memahami pentingnya perawatan nifas, mengetahui tentang ketersediaan pelayanan kesehatan, dan menggunakan informasi ini secara lebih efektif untuk memelihara atau mencapai kesehatan yang baik. Selain itu, wanita berpendidikan mungkin memiliki status sosial ekonomi yang lebih tinggi dan berdaya dalam pengambilan keputusan ibu terhadap pemanfaatan pelayanan kesehatan. ${ }^{12}$

Paritas berhubungan dengan kunjungan nifas lengkap di Indonesia. Ibu yang baru pertama kali melahirkan menganggap kunjungan masa nifas adalah hal yang baru, sehingga termotivasi untuk melakukan kunjungan pada masa nifas, berbeda halnya ibu yang memiliki paritas tinggi beranggapan bahwa sudah memiliki pengalaman yang cukup sehingga tidak perlu melakukan kunjungan masa nifas. ${ }^{13}$ Selain itu mereka juga sangat ingin mengetahui tentang kesehatan bayi mereka yang dapat diperoleh melalui tenaga kesehatan. ${ }^{14}$

Selain pendidikan dan paritas, tempat dan metode persalinan juga mempengaruhi ibu melakukan kunjungan nifas lengkap. Hal ini disebabkan karena ibu yang melahirkan di fasilitas kesehatan memiliki peluang lebih besar untuk mendapatkan pendidikan kesehatan terkait layanan nifas. Para tenaga kesehatan memberikan informasi dan mendukung ibu melakukan perawatan komprehensif, termasuk perawatan nifas segera setelah melahirkan. ${ }^{15} \mathrm{Di}$ pedesaan Uganda, wanita yang melahirkan di rumah dilarang meninggalkan rumah selama beberapa hari setelah anak lahir dan tidak diperbolehkan mencari perawatan tepat waktu karena mereka percaya bahwa komplikasi persalinan tersebut disebabkan oleh sihir. ${ }^{16} \mathrm{Ibu}$ yang melahirkan dengan sesar, vacuum, forceps, dll cenderung melakukan kunjungan nifas dibandingkan dengan ibu yang melahirkan normal. Hal ini disebabkan karena ibu yang melahirkan dengan operasi cenderung memiliki kerentanan yang lebih besar terhadap berbagai komplikasi pascaoperasi sehingga 
sering kembali ke pelayanan kesehatan untuk mencegah atau meminimalkan risiko yang dirasakan. ${ }^{17}$

Ibu dengan pemeriksaan kehamilan lengkap cenderung melakukan kunjungan nifas lengkap. Hal ini disebabkan karena pada pemeriksaan kehamilan, seorang ibu mendapatkan pelayanan dan konseling kesehatan serta mengenali secara dini adanya ketidaknormalan atau komplikasi yang mungkin terjadi selama ibu hamil, termasuk riwayat penyakit secara umum, kebidanan, dan pembedahan. ${ }^{18}$ Penyedia ANC menggunakan kesempatan untuk menginformasikan tentang pentingnya persalinan yang aman dengan tenaga kesehatan terlatih, pelatihan tanda-tanda komplikasi, bagaimana merencanakan bila terjadi gawat darurat, dan pentingnya menghadiri/memanfaatkan pelayanan nifas setelah melahirkan. Wanita yang mendapatkan perawatan antenatal memiliki pengaruh positif terhadap pemanfaatan pelayanan nifas karena berhubungan dengan pendidikan kesehatan dan konseling yang diterima selama kunjungan. Oleh sebab itu, promosi pemeriksaan kehamilan harus lebih ditingkatkan. ${ }^{19}$

Kepemilikan jaminan kesehatan atau asuransi mempengaruhi dalam pemanfaatan fasilitas kesehatan karena jaminan kesehatan atau asuransi kesehatan dapat menjamin masyarakat dalam memperoleh manfaat dalam pemeliharaan kesehatan dan perlindungan dalam memenuhi kebutuhan dasar Kesehatan. ${ }^{20}$ Dengan memiliki kartu BPJS maka aturan untuk kontrol berapa kalipun akan dilakukan oleh ibu asalkan ibu tidak dikenai biaya atau tarif dalam melakukan pemeriksaan nifas. ${ }^{21}$

Variabel yang signifikan berpengaruh terhadap kunjungan nifas dengan OR $<1$ antara lain umur, regional propinsi, status pekerjaan dan riwayat komplikasi kehamilan. Persentase kunjungan nifas lengkap lebih besar terjadi pada ibu yang berumur kurang 20 tahun diatas 35 tahun dibandingkan ibu yang berumur 20-35 tahun. Hal ini kemungkinan disebabkan karena ibu berpikir bahwa kehamilannya di usia yang ideal tidak akan menyebabkan risiko yang berarti sehingga mereka beranggapan bahwa pelaksanaan kunjungan nifas tidak terlalu penting. ${ }^{22}$

Kecenderungan kunjungan nifas lengkap lebih besar pada ibu yang tinggal di regional Nusa Tenggara-Maluku-Papua dibandingkan ibu yang tinggal di regional Sumatera, JawaBali, Kalimantan dan Sulawesi. Hal ini kemungkinan karena kondisi kesehatan di daerah Nusa Tenggara-Maluku-Papua masih kurang baik sehingga jumlah ibu yang mengalami gangguan/komplikasi selama kehamilan, persalinan dan masa nifas lebih banyak di daerah tersebut sehingga menyebabkan lebih tingginya kunjungan nifas lengkap.

Kecenderungan kunjungan nifas lengkap lebih besar pada ibu yang bekerja dibandingkan ibu yang tidak bekerja. Penelitian ini tidak sesuai dengan hasil penelitian yang mengatakan bahwa status pekerjaan adalah faktor pemungkin seorang ibu melakukan kunjungan nifas lengkap, dimana ibu yang tidak bekerja dapat melakukan kunjungan lebih sering karena memiliki banyak waktu luang. ${ }^{23}$ Hal ini kemungkinan karena perempuan yang tidak bekerja memiliki ekonomi yang rendah dan akibatnya mereka terhalang untuk memanfaatkan fasilitas kesehatan meskipun layanan tersebut direkomendasikan oleh petugas kesehatan. ${ }^{24}$

Wanita yang mengetahui memiliki komplikasi kehamilan selama kunjungan ANC dan mengetahui setidaknya satu tanda bahaya kebidanan postpartum lebih memanfaatkan pelayanan kunjungan nifas. Kesadaran akan tanda bahaya kebidanan merupakan faktor penting dalam memotivasi perempuan dan keluarganya untuk datang ke pelayanan kesehatan sedini mungkin dengan maksud untuk pencegahan, deteksi dini, dan penatalaksanaan tanda bahaya kebidanannya. ${ }^{25}$

Berdasarkan hasil analisis multivariat wilayah tempat tinggal tidak berhubungan dengan kunjungan nifas lengkap. Hasil penelitian ini tidak sejalan dengan penelitian yang menyatakan bahwa dimana ibu yang tinggal di perkotaan cenderung lebih memungkinkan untuk memanfaatkan pelayanan nifas. Hal ini disebabkan karena dekatnya fasilitas kesehatan, ketersediaan jalan dan transportasi yang lebih baik di perkotaan daripada di pedesaan dan pelayanan kesehatan terkonsentrasi di daerah perkotaan. ${ }^{26}$ Hasil penelitian ini sejalan dengan penelitian yang menyatakan bahwa hubungan tempat tinggal (perkotaan dan pedesaan) dengan pemanfaatan pelayanan nifas tidak bermakna kemungkinan disebabkan sudah meratanya bidan desa, pustu, polindes/poskesdes di desa-desa sehingga akses pelayanan nifas lebih baik. ${ }^{27}$

Hal yang juga menarik pada penelitian ini adalah bahwa riwayat komplikasi persalinan 
dan riwayat komplikasi nifas tidak mempengaruhi kunjungan nifas lengkap. Hal ini kemungkinan terjadi karena ketidaktauan ibu tentang tanda-tanda bahaya persalinan, bahaya masa nifas atau komplikasi masa nifas seperti perdarahan, demam, nyeri kepala hebat, anemia dan lain - lain. Ketidaktauan tersebut menyebabkan ibu tidak mencari pertolongan atau melakukan pemeriksaan masa nifas ke tenaga kesehatan atau ibu mencari pertolongan atau pengobatan secara tradisional sehingga jumlah ibu yang mengalami komplikasi masa nifas tidak mempengaruhi. ${ }^{25}$

\section{KESIMPULAN}

Hasil penelitian menunjukkan bahwa proporsi kunjungan nifas lengkap di Indonesia masih rendah. Adapun faktor predisposisi yang mempengaruhi kunjungan nifas lengkap tersebut adalah usia ibu, pendidikan, paritas, metode persalinan, tempat persalinan, pemeriksaan kehamilan dan regional propinsi. Faktor pemungkin yang mempengaruhi kunjungan nifas lengkap adalah status pekerjaan dan kepemilikan jaminan kesehatan. Faktor kebutuhan yang mempengaruhi kunjungan nifas lengkap adalah riwayat komplikasi kehamilan.

Adapun saran yang direkomendasikan oleh peneliti adalah meningkatkan penyuluhan tentang pentingnya kunjungan nifas lengkap oleh petugas kesehatan. Selain itu promosi tentang manfaat pemeriksaan kehamilan yang lengkap harus lebih ditingkatkan mengingat pemeriksaan kehamilan yang lengkap merupakan faktor yang paling dominan dalam mempengaruhi kunjungan nifas lengkap dibandingkan variabel bebas lainnya.

\section{DAFTAR REFERENSI}

1. ASEAN. Asean Sustainable Development Goals Indicators Baseline Report 2020

2. Databooks. Angka Kematian Ibu Indonesia Cenderung Turun. (dikutip 9 februari 2021) Tersedia pada https://databoks.katadata.co.id/datapubli sh/2019/10/08/tren-angka-kematian-ibudi-indonesia

3. UN. The Sustainable Development Agenda. 2015.

https://www.un.org/ga/search/view_doc. asp?symbol=A/RES/70/1\&Lang=E
4. Profil Kesehatan Indonesia Tahun 2019

5. Tessema, ZE, Yazachew L, Tesema GA, Thesale AB. 2020. Determinants of Postnatal Care Utilization in SubSaharan Africa: A Meta and Multilevel Analysis of Data From 36 Sub-Saharan Countries. Italian Journal of Pediatrics 46, Article number: 175 (2020)

6. WHO. Maternal Mortality. 2018. (Dikutip 26 Januari 2021) Tersedia pada https://www.who.int/news-room/factsheets/detail/maternal-mortality

7. Weisssmann-Brenner A, Heusler I, Manteka R, Dulitzky M, Baum M. Postpartum Visits in The Gynecological Emergency Room: How Can We Improve? BMC Pregnancy and Childbirth, 2020, vol (20), Article number: 278.

8. Achady E.L, 2017. Kematian Maternal dan Neonatal di Indonesia. Banten. Bahan Presentasi Rakernas 2019, Kemenkes RI.

9. Nurrizka AR, Wahyono TYM. Disparity of Maternal Mortality in Indonesia: Ecological Study with Spatial Analysis. Jurnal MKMI, 2018 Juni Vol (14) No 2.

10. Kemenkes RI. Panduan Pelayanan Pascapersalinan bagi Ibu dan Bayi Baru Lahir. 2019.

11. Kementerian Kesehatan RI. Riskesdas 2018 [Internet]. Riset Kesehatan Dasar 2018. 2018 (dikutip 26 Januari 2021) Tersedia pada https://www.litbang.kemkes.go.id/lapor an-riset-kesehatan-dasar-riskesdas/.

12. Bwalya BB, Mulenga MC, Mulenga JN. Factors Associated with Postnatal Care for New Born in Zambia: Analysis of The 2013-14 Zambia Demographic and Health Survey. BMC Pregnancy and Childbirth, 2017 17(1), 1-13. https://doi.org/10.1186/s12884-017$\underline{1612-1}$

13. Rosita M. Hubungan Antara Pendidikan, Usia dan Paritas Ibu Nifas dengan Kunjungan Masa Nifas Di Bidan Praktik Mandiri Suryati Palembang Tahun 2017. 
Jurnal Aisyiyah Medika ,2017 Februari, Vol (1).

14. Akibu M, Tsegaye W, Megersa T, Nurgi S. Prevalence and Determinants of Complete Postnatal Care Service Utilization in Northern Shoa, Ethiopia. Journal of Pregnancy, 2018, Article ID 8625437. | https://doi.org/10.1155/20 $\underline{18 / 8625437}$

15. Chola M, Chungu C, Makasa M, Jacobs C. Place of Delivery Associated with Postnatal Care Utilization among Childbearing Women in Zambi. Front Public Health, 2018 April 6:94.

16. Ndugga P, Namiyonga NK, Sebuwufu D. Determinants of Early Postnatal Care Attendance: Analysis of The 2016 Uganda Demographic and Health Survey. BMC Pregnancy and Childbirth, 2020, Vol 20, Article number: 163.

17. Mohammed Akibu, Wintana Tsegaye, Tewodros Megersa, \& Sodere Nurgi. Prevalence and Determinants of Complete Postnatal Care Service Utilization in Northern Shoa, Ethiopia. Journal of Pregnancy, 2018, Article ID 8625437. | https://doi.org/10.1155/20 $\underline{18 / 8625437}$

18. Permenkes RI Nomor 97 Tahun 2014 tentang Pelayanan Kesehatan Masa Sebelum Hamil, Masa Hamil,Persalinan, dan Masa, Sesudah Melahirkan, Penyelenggaraan Pelayanan Kontrasepsi, Serta Pelayanan Kesehatan Seksual. Kemenkes RI. 2014.

19. Nugraha, SM. Determinan Akses Pelayanan Nifas di Indonesia (Analisis Riskesdas 2010). [tesis]. Depok Jawa Barat: Fakultas Kesehatan Masyarakat UI.; 2013.

20. UU Nomor 40 Tahun 2004 Tentang Sistem Jaminan Sosial Nasional. Pemerintah Republik Indonesia. 2004.
21. Widyawati E. Hubungan Status Jaminan Kesehatan Nasional dengan Kepatuhan Kunjungan Ulang Ibu Nifas di Puskesmas Semen Kabupaten Kediri. Jurnal Kesehatan, 2019, Vol. 3 No. 2.

22. Pinaringsih T, Riyanti E, Kusumawati A. Faktor-faktor yang Berhubungan dengan Kunjungan Ibu Nifas ke Pelayanan Kesehatan di Wilayah Kerja Puskesmas Tlogosari Kulon Kota Semarang. Jurnal Kesehatan Masyarakat, 2017, Vol (5) No (3).

23. Rahmawati L, Khoiri A, Herawati YT. Faktor yang Berhubungan dengan Kunjungan Ibu Nifas di Wilayah Kerja Puskesmas Jelbuk Kabupaten Jember. Fakultas Kesehatan Masyarakat Universitas Jember; 2015.

24. Chakraborty N, Islam MA, Chowdhury RI, Bari W. Utilisation of postnatal Care in Bangladesh: evidence from a longitudinal study. Health Soc Care Community. 2002;10:492-502.

25. Nugraha, SM. Determinan Akses Pelayanan Nifas di Indonesia (Analisis Riskesdas 2010). [tesis]. Depok Jawa Barat: Fakultas Kesehatan Masyarakat UI.; 2013.

26. Tarekegn SM, Lieberman LS, Giedraitis V. Determinants of Maternal Health Service Utilization in Ethiopia: Analysis of The 2011 Ethiopian Demographic and Health Survey. BMC Pregnancy Childbirth, 2014 May Vol (14):161.

27. Astuti R. 2013. Faktor - faktor yang Berhubungan dengan Status Kunjungan Nifas (KF) Lengkap di Tingkat Kabupaten/Kota Tahun 2013 (Analisis Data Riskesdas Tahun 2013). [tesis]. Depok Jawa Barat: Fakultas Kesehatan Masyarakat UI.; 2015. 